保育園児の鼻咽腔ペニシリン耐性肺炎球菌

\author{
伊藤 真人・白井 明子・巽 亜希子 \\ 吉崎 智一・西村 俊郎・古川 仞
}

\title{
Incidence of Penicillin Resistant Streptococcus Pneumoniae in a Nursery School
}

\author{
Makoto Ito, Akiko Shirai, Akiko Tatsumi, Tomokazu Yoshizaki, \\ Toshiro Nishimura and Mitsuru Furukawa \\ (Kanazawa University)
}

\begin{abstract}
In order to investigate the bacteriologic and clinical interpretation of the flora of the nasopharynx from children $(n=31)$ and the staff $(n=15)$ in a nursery school, penicillin resistance $\left(\mathrm{Pc}^{\mathrm{r}}\right)$ of Streptococcus pneumoniae was examined. Chief bacteria from children were S. pneumoniae (27 strains, 87\%), Haemophilus influenzae (27 strains, 87\%) and Moraxella catarrhalis (24 strains, $80 \%$ ). Of the 27 strains of $S$. pneumoniae, 23 strains (85\%) were identified as a $\mathrm{Pc}^{\mathrm{r}} \mathrm{S}$. pneumoniae. Two children had recurrent episodes of acute otitis media, but no children showed the conditions of acute otitis media on the medical examination day. From these data, prevalence of $\mathrm{Pc}^{\mathrm{r}} S$. pneumoniae is very high in young children in nursery school in Japan.

On the other hand, chief bacteria from the staff were $H$. influenzae (8 strains, 47\%) and $M$. catarrhalis (2 strains, 12\%). S. pneumoniae was not detected in these healthy adults.
\end{abstract}

Key words : penicillin-resistant Streptococccus pneumoniae (PRSP), recurrent acute otitis media, nursery school

はじめに

近年, 市井に括いてペニシリン耐性肺炎球菌 (PRSP : penicillin G highly resistant S. pneumoniae, または PISP : penicillin G intermediately resistant $S$. pneumoniae) が急増して括り12), これら耐性菌による遷延する 小児気道感染症や, 反復性急性中耳炎の増加, さらには 䯣膜炎や重症肺炎症例が臨床上問題となっている3 ${ }^{34)}$. これら難治例では, 鼻咽腔の肺炎球菌を一時的でもよい から除菌すると, 症状は著明に改善することが報告され ている5)。しかし一旦消失した肺炎球菌が再び出現した り, 急性炎症が完全に消退した後にも肺炎球菌が鼻咽腔 に残存寸る症例も多く，鼻咽腔からの除菌の臨床的意義 については統一見解は得られていないのが現状である。
肺炎球菌は本来, 鼻咽腔の常在菌ではないかとも考兄 られているにもかかわらず6), 本邦に沶いて過去に行わ れたペニシリン耐性肺炎球菌に関する疫学調査の多くが, 急性中耳炎や気道感染症のために医療機関を受診した患 児を対象として扣り，急性炎症所見のみられない症例や， 健常人に怙ける鼻咽腔からのペニシリン耐性肺炎球菌の 検出状況についての知見はきわめて限られている.

一方で最近の報告によると, 治療に抵抗する急性中耳 炎の保育園内集団発生や，反復性急性中耳炎例の約 $80 \%$ が保育園児であるとの報告もみられる377)。これらの中 耳, 上気道感染症の危険因子として集団保育が注目され ているにもかかわらず, 本邦保育園に打ける肺炎球菌等 の細菌検出状況についての報告はみられない。これらの 
細菌, 特に耐性菌の感染経路や, 鼻咽腔の常在菌として の自然経過を知る上で，保育園に括ける細菌検出状況を 検討することは重要である.

今回我々は, 本邦健常人に批洔ぺニシリン耐性肺炎 球菌の検出状況の一端を明らかにするとともに，鼻咽腔 の肺炎球菌感染と実際の臨床症状発現との関係も検討す るために，保育園の園児 $(0 \sim 3$ 歳児 $)$ と職員を対象に調 査検討を行った。

\section{方法}

対象は金沢市内にある，0 歳児保育を行っている 育園の園児 30 名と, 保母执よび給食関係の職員15名であ
る。また当日休みのため検診できなかった園児 1 名は， 後日同様の検診を行ったので, 園児の総数は 31 名である. 鼻咽腔ぬぐい液の採取は同保育園の耳鼻咽喉科検診の一 部として行って扣り, 事前のアンケート調査時に父兄に 対して, 検診内容と鼻咽腔からの細菌検査を行ら旨を通 知し了解を得た。

アンケートの調査内容は表 1 に示したよらに，過去に 扣ける急性中耳炎, 參出性中耳炎, 気管支炎等の既往に つき，特に詳しく問診した．検診はインフルェンザの流 行の兆しがみ文始めた平成11年 1 月 6 日に施行した。実 際の検診内容は耳・鼻・ 口腔・咽頭の診察と, リオン社 製ポータブル型インピーダンス・オージオメーター

\section{表 1 T保育園・耳鼻咽喉科検診問診表}

1.お子さんの聞こえ（聴力）が気になりますか?

2. 鼻水は多いですか?

3.いびきは大きいですか?

4. よくかぜをひきますか?

5. 今までに渗出性中耳炎（中耳に水の貯まる中耳炎です。痛みはなく、聞こえにくさ が主症状です）といわれたことがありますか?

「はい」と答えられた方にお伺いします。

1) 沴出性中耳炎は難治性（治癒までに3カ月以上かかったもの）でしたか?

2) 渗出性中耳炎は絽り返していますか?

3）現在、治療中ですか?

6. 今までに急性中耳炎（痛みを伴う化膿性中耳炎です）といわれたことがありますか? 「はい」と答えられた方にお伺いします。

1）初めて急性中耳炎にかかったのは何歳でしたか?

1 歳未満 $\quad 1 \sim 2$ 歳未満 2 歳以上

2）その後、急性中耳炎を繰り返していますか?

おおよその頻度をお伺いします。以下からお選びください。

（複数回答可）

（1）6カ月間に、4回以上繰り返したことがある。

（2） 1 年間に、 5 回以上繰り返したことがある。

（3） 2 歳までに、5回以上繰り返したことがある。

（4）上記以外。おおよその回数がわかれば、ご記入ください。

記入例：「2力月間に3回、その後は䍜患せず」など

7. 今までに気管支炎や肺炎といわれたことがありますか?

「はいと答えられた方にお伺いします。

1）初めて気管支炎、肺炎にかかったのは何歳でしたか?

1 歳未満 $\quad 1 \sim 2$ 歳未満 2 歳以上

2）その後気管支炎、肺炎を繰り返していますか?

3）気管支炎、肺炎で入院加療を受けたことがありますか?

8. その他、耳・鼻・のどでお気づきの症状や相談したい内容がありましたら、ご記入く ださい。 


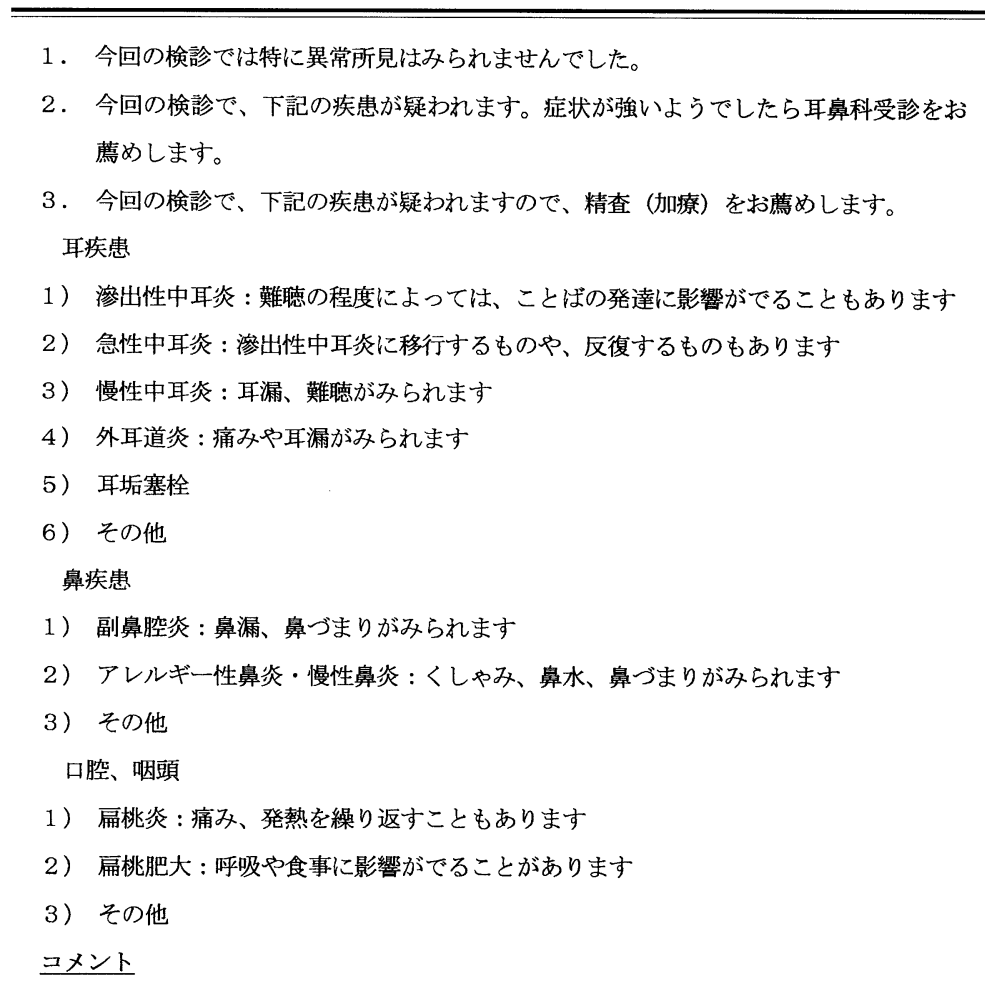

(RS-31) によるティンパノグラムの計測, 鼻咽腔ぬぐい 液の採取を行った。細菌検査の検体は即日, 「肺炎球菌 等による市中感染症研究会」を通して微生物化学研究会 附属微生物化学研究所に送付し, PCR 法を用いた肺炎 球菌・インフルェンザ菌の耐性遺伝子の検索を行った. 検診結果の父兄への報告は表 2 のよらな文書で行い，そ れぞれ必要なコメントを書き添えた。

\section{結＼cjkstart果}

検診の細菌学的結果を表 3,4 に示す. 園児からは(表 3 ), 急性中耳炎の 3 大起炎菌といわれる肺炎球菌, イ ンフルェンザ菌, モラキセラ・カタラーリスが非常に高 率に検出された. 各菌の検出率は肺炎球菌が31例中27例

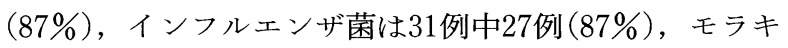

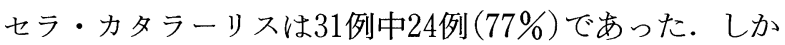
も多くの症例でこれらの 3 大起炎菌が複数菌として検出 された.さらに菌の検出菌量も (H) と多い園児も相当数 に確認された(表 5 )。ところが職員の方からは，インフ ルェンザ菌が 7 例 (47\%)，モラキセラ・カタラーリスも 2 例(13\%)から検出されているにもかかわらず，肺炎球 菌が検出された例は 1 例も又られなかった（表 4 )。 また，
菌の検出量も $(+N)$ と多い例はみられなかった.

園児の検出菌量と検鏡による白血球浸潤像との関係を 示したのが表 6 である. 検出菌量が (H) と多い園児から も, 白血球の浸潤像が $($ 卅) と強い炎症像を示すような症 例は認められず，検出菌量と検鏡による白血球像との間 には明らかな相関関係は認められなかった。

PCR 法による肺炎球菌の薬剤耐性をみたのが，図 1 である．園児から肺炎球菌が検出された 27 例中 23 例 $(85$ \%)が，ペニシリン耐性菌であり，これは今回調査を 行った全園児31例の，実に $74 \%$ といら高率にペニシリン 耐性肺炎球菌が認められたことを示している。

これを年齢別にみたのが図 2 である. 2 歳未満では全 例からペニシリン耐性肺炎球菌が検出されて扣り，また 3 歳未満では検出された肺炎球菌は全てぺニシリン耐性 菌であった． 3 歳児では肺炎球菌の割合が低下するとと もに，検出された肺炎球菌の多くがペニシリン感受性菌 (PSSP : penicillin G susceptible S. pneumoniae) であっ た。 0 歳児では全例で PRSP が検出され，1歳児では 9 例中 6 例が PRSP で， 2 例が PISP であった。残る 1 例は常在菌の発育が強く, 肺炎球菌の釣菌ができな かった症例であった。 2 歳児では12例中 PRSP が 4 例， 
表 3 園児の鼻咽腔からの細菌検出状況

\begin{tabular}{|c|c|c|c|c|c|c|c|c|c|}
\hline クラス & No & 年齢 & 性 & S.pn & $\begin{array}{l}\text { 出 } \\
\text { H.inf }\end{array}$ & M. cat & $\begin{array}{c}\text { S.pn } \\
\text { 耐性判定 }\end{array}$ & $\begin{array}{l}\text { S.pn } \\
\text { 血清型 }\end{array}$ & $\begin{array}{c}\text { H.inf } \\
\text { 耐性判定 }\end{array}$ \\
\hline \multirow{9}{*}{ A } & 園児 1 & 3 歳 6 力月 & 女 & - & - & H & - & & - \\
\hline & 園児 2 & 3 歳 5 力月 & 女 & H & + & $H$ & S & 6 型 & $\mathrm{S}$ \\
\hline & 園児 3 & 3 歳 4 力月 & 男 & + & + & H & S & 15型 & S \\
\hline & 園児 4 & 3 歳 3 力月 & 女 & - & m & $H$ & - & & S \\
\hline & 園児 5 & 3 歳 1 力月 & 男 & $H$ & H & H & I & 19型 & S \\
\hline & 園児 6 & 3 歳 1 力月 & 女 & H & + & + & S & 6 型 & S \\
\hline & 園児 7 & 2 歳 10 力月 & 女 & H & + & + & I & 6 型 & S \\
\hline & 園児 8 & 2 歳 9 力月 & 男 & H & H & + & I & 6 型 & S \\
\hline & 園児 $9 *$ & 2 歳 8 力月 & 女 & + & + & - & I & NT & $\mathrm{S}$ \\
\hline \multirow{9}{*}{ B } & 園児10 & 2 歳 8 力月 & 男 & H & $H$ & + & I & 6 型 & $\mathrm{S}$ \\
\hline & 園児11 & 2 歳 7 力月 & 男 & + & H & - & $\mathrm{R}$ & 6 型 & $\beta$-lac \\
\hline & 園児12 & 2 歳 6 力月 & 女 & H & + & H & I & 6 型 & $\mathrm{S}$ \\
\hline & 園児13 & 2 歳 6 力月 & 女 & m & H & H & I & 6 型 & S \\
\hline & 園児14 & 2 歳 6 力月 & 女 & + & H & H & $\mathrm{R}$ & 23型 & $\mathrm{S}$ \\
\hline & 園児15 & 2 歳 5 力月 & 男 & - & - & H & - & & - \\
\hline & 園児16 & 2 歳 5 力月 & 男 & H & H & + & $\mathrm{R}$ & 6 型 & $\beta$-lac \\
\hline & 園児 $17^{* *}$ & 2 歳 3 力月 & 男 & H & H & - & $\mathrm{R}$ & $?$ & BLNAR \\
\hline & 園児18 & 2 歳 2 力月 & 男 & - & - & H & - & & - \\
\hline \multirow{6}{*}{$\mathrm{C}$} & 園児19 & 1 歳 9 力月 & 女 & + & + & H & $\mathrm{R}$ & 6 型 & BLNAR \\
\hline & 園児20 & 1 歳 7 力月 & 男 & $H$ & H & H & $\mathrm{R}$ & 19型 & S \\
\hline & 園児21 & 1 歳 7 力月 & 男 & H & H & H & I & 6 型 & BLNAR \\
\hline & 園児22 & 1 歳 6 力月 & 女 & H & $H$ & - & $\mathrm{R}$ & 6 型 & BLNAR \\
\hline & 園児23 & 1 歳 5 力月 & 男 & H & $H$ & + & $\mathrm{R}$ & 6 型 & BLNAR \\
\hline & 園児24 & 1 歳 4 力月 & 女 & + & + & - & $?$ & & S \\
\hline \multirow{7}{*}{ D } & 園児25 & 1 歳 2 力月 & 男 & + & $H$ & - & $\mathrm{R}$ & 19型 & BLNAR \\
\hline & 園児26 & 1 歳 2 力月 & 男 & H & H & H & I & 6 型 & S \\
\hline & 園児27 & 1 歳 2 力月 & 男 & + & + & H & $\mathrm{R}$ & 19型 & $\mathrm{S}$ \\
\hline & 園児28 & 0 歳11力月 & 女 & H & $H$ & + & $\mathrm{R}$ & 23型 & S \\
\hline & 園児29 & 0 歳11力月 & 男 & H & + & - & $\mathrm{R}$ & 23型 & $\mathrm{S}$ \\
\hline & 園児30 & 0 歳 10 力月 & 女 & H & - & + & $\mathrm{R}$ & $?$ & - \\
\hline & 園児31 & 0 歳 9 力月 & 男 & + & + & H & $\mathrm{R}$ & 23型 & $\beta$-lac \\
\hline
\end{tabular}

S.pn : 肺炎球菌, H.inf : インフルェンザ菌, M.cat : モラキセラ・カタラーリス

S. pn 耐性判定の項の S : PSSP, I : PISP, R : PRSP

H.inf 耐性判定の項の $\mathrm{S}$ : 感受性菌, BLNAR : 軽度耐性菌ともいえる $\beta$-lactamase negative ampicillin resistant 株 $\beta$-lac : 高度耐性を示す $\beta$-ラクタマーゼ産生株

園児 $9^{*}$ : 反復性中耳炎の既往，滲出性中耳炎 $(+)$

園児 $17^{* *}$ : 反復性中耳炎，気管支炎の既往

PISP が 6 例であり，PRSP と PISP の比率の逆転現象 が観察さ扎た。他の 2 例からは肺炎球菌そのものが検出 されなかった． 3 歳児では 6 例中 4 例のみ肺炎球菌が検 出され，このうち耐性菌はPISP の 1 例のみであり，他 はPSSP であった。 また, 今回の検診では 2 歳 8 カ月 を過ぎると PRSP は 1 例もみられなかった。

一方インフルェンザ菌の薬剂耐性をみてみると（表
3 ), 高度耐性を示す $\beta$-ラクタマーゼ産生株は 3 例から, 軽度耐性ともい光る BLNAR ( $\beta$-lactamase negative ampicillin resistance) 株は 5 例からみられ，これは 1 歳児 で集中して検出された。

これらの小児の既往歴と臨床所見をまとめたものが表 7 である. 急性中耳炎の既往がある園児は 2 歳以上の 7 例のみであり，このうち山中の定義8) そ基づく反復性中 
表 4 職員の鼻咽腔からの細菌検出状沉

\begin{tabular}{|c|c|c|c|c|c|c|}
\hline No & 性 & S. pn & $\begin{array}{l}\text { 出 } \\
\text { H.inf }\end{array}$ & M. cat & $\begin{array}{c}\text { S.pn } \\
\text { 耐性判定 }\end{array}$ & $\begin{array}{c}\text { H.inf } \\
\text { 耐性判定 }\end{array}$ \\
\hline 職員 1 & 女 & - & - & - & - & - \\
\hline 職員 2 & 女 & - & - & - & - & - \\
\hline 職員 3 & 女 & - & - & + & - & - \\
\hline 職員 4 & 女 & - & - & - & - & - \\
\hline 職員 5 & 女 & - & - & H & - & - \\
\hline 職員 6 & 女 & - & + & - & - & $S$ \\
\hline 職員 7 & 女 & - & - & - & - & - \\
\hline 職員 8 & 女 & - & + & - & - & BLNAR \\
\hline 職員 9 & 女 & - & - & - & - & - \\
\hline 職員 10 & 女 & - & - & - & - & - \\
\hline 職員11 & 女 & - & H & - & - & $\beta$-lac \\
\hline 職員 12 & 女 & - & + & - & - & BLNAR \\
\hline 職員 13 & 女 & - & $H$ & - & - & S \\
\hline 職員 14 & 女 & - & + & - & - & S \\
\hline 職員15 & 女 & - & + & - & - & S \\
\hline
\end{tabular}

表 5 園览・職員の鼻咽腔からの検出菌量

\begin{tabular}{|c|c|c|c|c|}
\hline \multirow{2}{*}{$\begin{array}{l}\text { 園児: } 31 \text { 名 } \\
\quad 0 \sim 3 \text { 歳 }\end{array}$} & \multicolumn{2}{|r|}{ 検 出 } & \multicolumn{2}{|l|}{ 量 } \\
\hline & (H) & $(H)$ & $(+)$ & $(-)$ \\
\hline $\begin{array}{c}\text { 肺炎球菌 } \\
\text { インフルェンザ菌 } \\
\text { モラキセラ・カタラーリス }\end{array}$ & $\begin{array}{ll}6 & (19 \%) \\
4 & (13 \%) \\
3 & (10 \%)\end{array}$ & $\begin{array}{ll}12 & (39 \%) \\
12 & (39 \%) \\
14 & (45 \%)\end{array}$ & $\begin{aligned} 9 & (29 \%) \\
11 & (35 \%) \\
7 & (23 \%)\end{aligned}$ & $\begin{array}{ll}4 & (13 \%) \\
4 & (13 \%) \\
7 & (23 \%)\end{array}$ \\
\hline \multirow{2}{*}{ 職員：15名 } & \multicolumn{4}{|c|}{ 検 出 } \\
\hline & (HI) & $(H)$ & $(+)$ & $(-)$ \\
\hline $\begin{array}{c}\text { 肺炎球菌 } \\
\text { インフルェンザ菌 } \\
\text { モラキセラ・カタラーリス }\end{array}$ & $\begin{array}{l}0(0 \%) \\
0(0 \%) \\
0(0 \%)\end{array}$ & $\begin{array}{l}0(0 \%) \\
2(13 \%) \\
1(6 \%)\end{array}$ & $\begin{array}{ll}0 & (0 \%) \\
5 & (33 \%) \\
1 & (6 \%)\end{array}$ & $\begin{aligned} 15 & (100 \%) \\
8 & (53 \%) \\
13 & (87 \%)\end{aligned}$ \\
\hline
\end{tabular}

「肺炎球菌等による市中感染症研究会速報」より改変

耳炎の既往があるものは, 肺炎球菌検出例27例中 2 例 (約 $7 \%)$ のであった。一方で気管支炎・肺炎の既往は 7 例にみられ，2 歳未満の園児では気管支炎の既往が 3 例 でみられた以外は，急性感染がみられた症例はなかった。 ただしこの 3 例中， 2 例では気管支炎は難治であり，入 院のう光抗菌剤の静注療法が必要であった。

鼓膜所見上，検診時に急性中耳炎を認めた症例は 1 例 もなかったが，ティンパノグラムでB型を示した症例は 14例に達し, 特に 2 歳未満の症例では高率に B 型を示し て拉り，參出性中耳炎の合併例が多いことが指摘された。
粘性・膿性の鼻漏, 後鼻漏は12例で確認され, 漿液性 の鼻漏や少量の鼻漏の例を含める之, 全園児31例中19例 (61\%)で何らかの鼻症状を伴っていたが，特に 1，2 歳 児の肺炎球菌検出例では高率に鼻症状が認められた。

\section{考察}

近年, ペニシリン耐性肺炎球菌の増加に伴い, 遷延す る小児気道感染症や, 反復する急性中耳炎が臨床上問題 となっている314)。ささらはは治療を䛊ると致死的なこと も多い，PRSP による小児の細菌性髄膜炎や大葉性肺炎 
表 6 園児の鼻咽腔からの検出細菌と, 検鏡に打ける白血球浸出像との関係

\begin{tabular}{c|c|c|c|c|c}
\hline \hline \multirow{2}{*}{ 検 出 細 菌 } & \multirow{2}{*}{ 検出菌量 } & \multicolumn{4}{|c|}{ 白 血 球 像 } \\
\cline { 3 - 6 } & & $(-) \sim(+)$ & $(+)$ & $(+)$ & $(++)$ \\
\hline 肺炎球菌 & $(+H)$ & 0 & 4 & 2 & 0 \\
\hline & $(+)$ & 4 & 4 & 4 & 0 \\
\hline & $(+)$ & 4 & 4 & 1 & 0 \\
\hline
\end{tabular}

\begin{tabular}{l|l|l|l|l|l}
\hline インフルエンザ菌 & $(\mathrm{m})$ & 1 & 1 & 2 & 0 \\
\hline & $(+)$ & 2 & 7 & 4 & 0 \\
\hline & $(+)$ & 5 & 4 & 1 & 0 \\
\hline & $(-)$ & 1 & 1 & 0 & 0
\end{tabular}

\begin{tabular}{c|c|c|c|c|c}
\hline モラキセラ・カタラーリス & $(\mathrm{H})$ & 0 & 2 & 1 & 0 \\
\hline & $(+)$ & 4 & 6 & 4 & 0 \\
\hline & $(+)$ & 3 & 3 & 1 & 0 \\
\hline & $(-)$ & 4 & 2 & 0 & 0 \\
\hline 計 & & $11(35 \%)$ & $13(42 \%)$ & $7(23 \%)$ & $0(0 \%)$
\end{tabular}

「肺炎球菌等による市中感染症研究会速報」より改变

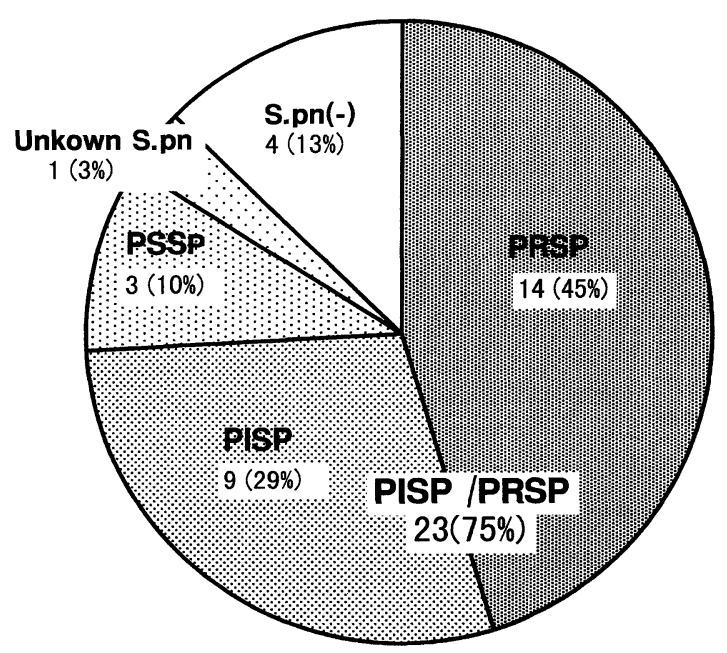

図 1 保育園児 $(0 \sim 3$ 歳児 $)$ からの肺炎球菌検出率 全園児31名中27名から肺炎球菌が検出された. Unkown S.pn : 肺炎球菌がみられたが, 常在菌の発育が強く, 肺炎球菌の釣菌ができなかった症例, S.pn(一) : 肺炎球 菌が検出されなかった症例.

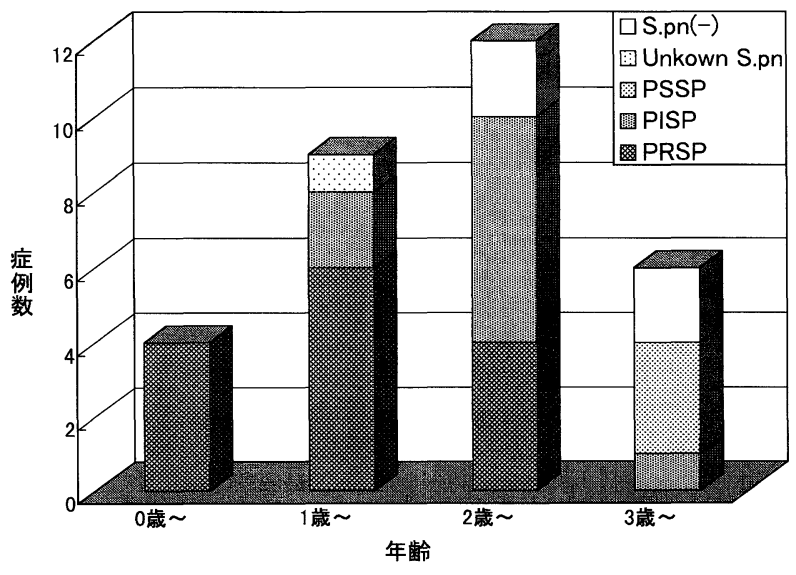

図 2 年齢別肺炎球菌検出率

2 歳以下の園児からは高率にペニシリン耐性肺炎球菌が 検出された. 
表 7 園児の既往歴と臨床所見

\begin{tabular}{|c|c|c|c|c|c|c|}
\hline & \multicolumn{3}{|c|}{ 既 往 歴 } & \multicolumn{3}{|c|}{ 臨 床 所 見 } \\
\hline & 急性中耳炎 & 反復性中耳炎 & 気管支炎 & Tympano B 型 & 鼻 & 漏 \\
\hline 0 歳（4 例） & 0 & 0 & 0 & 3 & & \\
\hline 1 歳（9 例） & 0 & 0 & 3 & 7 & & \\
\hline 2 歳（12例） & 3 & 2 & 3 & 3 & & \\
\hline 3 歳 (6 例) & 4 & 0 & 4 & 1 & & \\
\hline
\end{tabular}

Tympano : ティンパノグラム

の報告も散見されるようになってきている99.肺炎球菌 はインフルェンザ菌, モラキセラ・カタラーリスととも 飞急性中耳炎の 3 大起炎菌といわれ，明らかな病原性を 発揮する細菌であるにもかかわらず，健常者の鼻咽腔か らもよく検出される菌であり, 本来鼻咽腔に常在する菌 ではないかとも考壳られている。しかし市井に括ける， 健常人や急性炎症所見の及られない対象からの，菌の検 出状況や肺炎球菌全体に占めるペニシリン耐性菌の割合 についての知見はきわめて限られている。

今回行った検討目的の第一は, 健常人に和けるペニシ リン耐性肺炎球菌の検出状況を明らかにすることであっ た. しかし保育園といら環境は各種感染症の集団感染を 引き起こしやすい，いわば健常群ではあるが感染症に とってはハイ・リスク群ともい党る集団であることに留 意せねばならない，最近では小児反復性中耳炎症例の約 80\%が保育園児であったとの報告もみられ3)，反復感染 発症の危険因子としての集団保育といら環境因子の重要 性が示唆されている。しかしながら逆に，保育園児の全 てが反復感染症で治療を受けているわけではなく，保育 園児に括ける反復感染症例の発症頻度については不明で あった。

今回の我々の検討では，保育園児の活とんど全ての症 例から肺炎球菌が検出されて括り，これは急性中耳炎や 急性上気道炎等に括沙る鼻咽腔妨ぐ液からの, 肺炎球 菌検出率である30～56\% 114)10) をはるかに上回るもので あり，集団保育の場に批ける肺炎球菌の蔓延率が予想以 上に高いものであることが判明した。同時にその他のイ ンフルェンザ菌やモラキセラ・カタラーリスもまた，急 性炎症のみられる症例での検出率をはるか火上回る検出 率であり，乙かもこれら 3 大起炎菌は重複菌として検出 されていた.

さらに，ペニシリン耐性肺炎球菌の占める割合もきわ
めて高く, 特に 2 歳以下では検出された肺炎球菌は全例 がペニシリン耐性であり, 2 歳以下の症例25例中 22 例 (88 \%)からペニシリン耐性肺炎球菌が検出された。 このこ とは集団保育下の低年齢園児の鼻咽腔細菌叢の現状を示 している． 0 歳児を含めた低年龄児保育園といらのは本 邦ではまだ絶対数は少なく, やや特殊なハイ・リスク環 境下の細菌検出率とい觉る。しかし，ますます低年齢児 の保育人数の増加が見込まれる現状に执いて，問題とな るのはこれらの細菌の病原性と反復感染症例の発症頻度 である，そこで次に，鼻咽腔の肺炎球菌感染と実際の臨 床症状発現との関係を検討した。

今回調查した保育園児は検診当日, 発熱・咳などの明 らかな急性炎症症状を伴わない園児の久であり, 実際検 診結果でも急性の細菌感染や炎症所見は全くみられず, 既往歷でる難治性の中耳炎や上気道炎はわずか 2 例化認 められたのみであった．このことは鼻咽腔からペニシリ ン耐性肺炎球菌が検出される症例のらち, 限られた一部 の症例の久が難治性の上気道炎や中耳炎, さらには髄膜 炎や大葉性肺炎などの重症化を引き起こすことを示して いる.

このことは鼻咽腔ぬぐい液中の白血球浸潤像が, 強い 炎症所見を示す $(+\#)$ の症例が全くなく, 菌量の多い(H) の症例でも白血球像は (H) どまりであったこととも関係 している.肺炎球菌はいら子病原性を発揮する細菌では なく, 通常は小児の鼻咽腔に常在菌として存在するが, 宿主側の状態の変化によって病原性を発揮すると考兄ら れている。したがって, 起炎菌の同定には臨床所見や細 菌検査上の白血球浸潤像などが重要な判断基準となる. しかしながら，生後 6 カ月以内に急性中耳炎に罹患した 患児では，より中耳炎を反復する確率が高いことが判明 してきて招り11)，今回の検診でも耐性肺炎球菌が検出さ れた 27 例中の 2 例, 約 $7 \%$ に難治性の中耳炎や上気道炎 
がみられたという事実は, 保育園とくにこれら 0 歳児の 保育を行う乳幼児保育園といら環境が，各種の難治性感 染症の重要な危険因子であることを物語っている.

さらに，いわゆる慢性炎症としての鼻副鼻腔炎や，急 性中耳炎の後遺症としてもみられることの多い滲出性中 耳炎が，これらの鼻咽腔感染症例に执いて高率に認めら れたことは, 鼻咽腔の肺炎球菌感染症とこれら疾患の慢 性化との間に，何らかの因果関係があることを強く示唆 しているとい光よう。これについては，さらなる検討が 必要である.

以上の結果から, 肺炎球菌はインフルェンザ菌, モラ キセラ・カタラーリスらとともに, 乳幼児鼻咽腔の常在 菌とも考兄られるが，宿主側の要因により以下の 3 つに 分けて考学るのが望ましい。

1. 健康保菌者：全く無症状であるが，今後発症の可 能性はある。

2. 軽症発症者：副鼻腔炎・渗出性中耳炎などを認め る症例．因果関係についてはさらな る検討が必要である。

3. 重症発症者: 反復性中耳炎や遷延する上気道炎, さらには細菌性髄膜炎や大葉性肺炎 を引き起こすもの.

つまり急性細菌感染の所見に之しく, 一見, 健康保菌者 のようにみ兄る症例の中には相当数の軽症発症者が隠れ ている可能性がある.

今回, 保育園職員からも同時に鼻咽腔ぬぐい液を採取 し，成人と小児の菌検出率を比較検討したところ，成人 からは肺炎球菌は全く検出されなかった。一方で欧米の 文献では，成人の肺炎球菌感染症が比較的多くみられる ことが知られている12)。本邦に沶いては欧米とは異なり 健康成人からは肺炎球菌はほとんど検出されないのであ ろらか？今回調べた園児の中の 1 例では, 母親が産裖 期に一過性に，園児と同じ血清型のペニシリン耐性肺炎 球菌感染による上気道炎が遷延化した例があり，他にも 同様の家族内発生の報告がみられている7)。やはり感染 症状の発症には免疫能などの宿主側の要因が強く関与す るものと思われるが，健康成人の鼻咽腔からのペニシリ ン耐性肺炎球菌の検出頻度については，今後の検討が必 要である。

以上のことから，鼻咽腔からペニシリン耐性肺炎球菌 が検出される全ての症例に执いて鼻咽腔の完全な除菌を 行う必要性はないことは明らかであるが，同時に難治例
・重症例などの有症状例では積極的なペニシリン耐性肺 炎球菌の除菌が望ましいこともまた，臨床経験から明ら かな事実である。しかしながら，常用量の内服抗菌剂に よる鼻咽腔ペニシリン耐性肺炎球菌の除菌は難しく, 入 院の上抗菌剤の点滴静注によって一旦は菌の消失をみて も, 退院後に再び急性炎症を繰り返しペニシリン耐性肺 炎球菌が再出現する症例も多く, 治療に難渋しているの が現状である.このように抗菌剤のみに頼った肺炎球菌 感染症の治療は, もはや限界に達しているといわざるを 得ない，今後は免疫療法やアデノイド切除術などの抗菌 剤以外の治療法と，抗菌剤療法とを組み合わせたペニシ リン而性肺炎球菌の治療法を検討するとともに，この感 染症が実際に病原菌として影響を及洼している臨床症状 の範囲についてのさらなる検討が必要である。さらに同 一保育園に括ける肺炎球菌検出状況や血清型の経時的な 検討を通して，これらの菌が小児の鼻咽腔に常在するに あたっての感染経路や，自然消失の有無などの自然経過 を知る必要があると考光られる。

稿を終えるにあたり，御助言と御協力を頂きました，微生物 化学研究会附属微生物化学研究所, 生方公子先生飞感謝の意を 表します。

\section{参考文献}

1) 絊野昌俊, 吉田 繁, 井上真美子, 他：全国各地で分離さ れた肺炎球菌の疫学的研究. 感染症誌 $68: 1338 \sim 1351$, 1994.

2 ) Appelbaum PC : Antimicrobial resistance in Streptococcus pneumoniae; an overview. Clin Infect Dis $15: 77 \sim 83$, 1992.

3 ）小林俊光, 末武光子, 保富宗城, 他 : 反復性中耳炎の病態 と治療. 耳展 $42: 73 \sim 97,1999$.

4 ) 紺野昌俊, 生方公子 : 肺炎球菌検出例の背景. 改訂ペニシ リン耐性肺炎球菌(紺野昌俊編). 53 64頁, 協和企画通信, 東京, 1999 .

5 ）杉田麟也：耳鼻咽喉科感染症に括けるペニシリン低感受性 肺炎球菌の問題点. 臨床と微生物 $22: 193 \sim 202,1995$.

6 ) 中塩哲士 : penicillin G 低感受性菌/而性菌 検出状況 市井一次医療機関に打汀る検出状況一。臨床と微生物 22 ： $161 \sim 165,1995$.

7 ) 紺野昌俊 : 再検討が迫られる市中感染症 一PRSP, BLNAR を中心に一. Jpn J Antibiot 52 Suppl B : 105〜 107, 1999.

8 ) 山中 昇：反復性中耳炎とワクチン予防の可能性. 耳鼻臨 床 $87: 869 \sim 877,1994$.

9 ）紺野昌俊，生方公子：ペニシリン耐性肺炎球菌の臨床的意 
義と将来への展望. 改訂ペニシリン耐性肺炎球菌(紺野昌 俊編). 131 157頁, 協和企画通信, 東京, 1999 .

10）生方公子, 高橋洋子, 紺野昌俊, 他: 小児の急性気道感染 症に打ける肺炎球菌検出の状沉と薬剤感受性. 小児科臨床 $28: 1292 \sim 1297,1975$.

11) Harsten G, Prellner K, Heldrup J, et al : Recurrent acute otitis media. Acta Otolaryngol (Stockh) $107: 111 \sim 119$, 1989.

12) David WT : Pneumococcal infections. Textbook of Pedi- atric Infectious Diseases. 4th ed. Vol. 1 (ed by Ralh DF and James DC). pp 1129 1136, W.B. Saunders Company, Phladelphia, 1998.

$$
\begin{aligned}
& \text { 原稿受付 : 平成 } 11 \text { 年 } 5 \text { 月 } 26 \text { 日 } \\
& \text { 原稿採択 : 平成 } 11 \text { 年 } 6 \text { 月 } 16 \text { 日 急載 } \\
& \text { 別刷請求先 : 伊藤真人 } \\
& \text { † } 920-0934 \text { 金沢市宝町 } 13-1 \\
& \text { 金沢大学耳鼻咽喉科学教室 }
\end{aligned}
$$

